\title{
Effectiveness of Poverty Alleviation Policy (A Study on the Policy of Poverty Alleviation Gerbang Sadu Mandara)
}

\author{
Toto Noerasto \\ Student of Doctor Study Program of Administration Sciences - FISIP, Universitas 17 Agustus 1945 Surabaya, \\ Jl. Semolowaru No. 45 Surabaya, Jawa Timur, Indonesia \\ V. Rudy Handoko
}

Arif Darmawan

Anak Agung Gede Oka Wisnumurti

\begin{abstract}
Since 2012 the Government of Bali Province has developed a for poverty alleviation program called Mandara Integrated Village Development Movement or Gerbang Sadu Mandara (GSM). Budgeting policy of the program was firstly stipulated in a Regulation of the Government of Bali Province Number 11 Year 2011 on the 2012 Budget, Revenue, and Expenditure of Bali. What distinguishes GSM from previous similar programs implemented by the government includes the amount of money distributed to the villages in the GSM program is relatively very much, that is 1.2 billion rupiahs.

Bungaya Village, Bebandem District, is one of the villages in Karangasem Regency became the target of GSM because it has poverty rate over than $35 \%$.

The research applies descriptive qualitative analysis. It focuses on the problems of the effectiveness of the GSM Program on poverty alleviation and the factors becoming obstacles the program, and effective policy implementation model in reducing poverty at Bungaya Village, Bebandem District, Karangasem Regency.

The result of the research shows that the GSM program implemented at Bungaya Village is less effective (below $50 \%$ ) in reducing poverty because it only reaches $34.15 \%$ receiving the program and only $38.18 \%$ could complete the program. Even though it is categorized as less effective, the program implementation has run well and received good responses from the community.

The GSM Program is not effective in reducing poverty at Bungaya Village, Bebandem District, Karangasem Regency because the participation of poor groups in the decision-making processes as from planning, implementation, and evaluation is very limited. The other factor obstructing the ineffectiveness of GSM Program at the village is the formal and informal policy makers at the village did not contribute extensively in the program. Other agendas such as politic, social, and religion agendas were also carried out at the same period when the GSM program was being implemented at the village.

Based on the results of the research, reconstruction of poverty alleviation policy models should be tried to encourage poverty alleviation spirit by promoting collective awareness in order the village understands that poverty is a common enemy and increasing the participation of all parties in eradicating poverty.
\end{abstract}

Keywords: Government, budgeting policy, qualitative analysis, program implementation

DOI: $10.7176 /$ PPAR/10-7-04

Publication date:July $31^{\text {st }} 2020$

\section{Background}

Since 2012, the Provincial Government of Bali has been developing a poverty alleviation program / activity called the Mandara Integrated Village Development Movement/ Gerbang Sadu Mandara (GSM). This program budgeting policy was first stipulated in the Provincial Regulation of Bali Province Number 11 of 2011 Concerning the 2012 Regional Revenue and Expenditure Budget. It's financial technical program is regulated in Bali Governor Regulation Number 37 of 2012 concerning Technical Guidelines for Special Financial Assistance to 77 Villages / Villages Through the Mandara Integrated Village Development Movement Program / Activity (Gerbang Sadu Mandara) in the Province of Bali.

The thing that distinguishes the Program/ Activity of the Mandara Integrated Village Development Movement with previous similar program that implemented by the government is the nominal amount of money channeled to villages in the GSM program is relatively very large, namely one point two billion rupiah. This program uses a participatory approach and a system for submitting proposals to BUMDes as the program manager in the village which is very simple, making it easier for the community to access this program.

The Mandara Integrated Village Development Movement / (Gerbang Sadu Mandara) (GSM) seeks to encourage village development based on the socio-economic community. Furthermore, Gerbang Sadu Mandara is expected to be able to encourage the independence of the community and villages in developing themselves and 
their environment independently through increased income, and can support the implementation of Law Number 25 of 2004 concerning the National Development Planning System (SPPN) and Government Regulation Number 72 of 2005 concerning Village. Therefore, the Provincial Government of Bali is committed to continuing this program with the aim that poverty in the Balinese community can be overcome to the maximum.

Bungaya Village at Bebandem Subdistrict, is one of the villages in Karangasem Regency which was targeted by the Gerbang Sadu Mandara Program with a level of poverty above 35\%. For more effective implementation of the Gerbang Sadu Mandara program, the government sees the need for a team to oversee activities ranging from determining villages that have or have not been entitled to assistance to evaluation activities. Effectiveness is a basic element to achieve the goals or objectives that have been determined in every organization. In this case, the effectiveness is essentially the utilization of resources, facilities and infrastructure in a certain amount that is consciously determined in advance to produce a number of jobs on time. Effectiveness shows success in terms of whether or not the target has been set. If the results of the activities are closer to the target, the effectiveness will be higher.

\subsection{Problem Formulation}

1. What is the Effectiveness of the Gerbang Sadu Mandara (GSM) Program on poverty alleviation in Bungaya Village at Bebandem District, Karangasem Regency?

2. What factors are obstacles to the implementation of the Gerbang Sadu Mandara program in Bungaya Village at Bebandem District, Karangasem Regency?

3. What is the model for effective policy implementation for poverty alleviation in Bungaya Village, Bebandem District at Karangasem Regency?

\subsection{Research Objectives}

1. To analyze the effectiveness of the Gerbang Sadu Mandara (GSM) program in poverty reduction in Bungaya Village at Bebandem District, Karangasem Regency.

2. To analyze what factors hampered the implementation of the Gerbang Sadu Mandara (GSM) program in Bungaya Village at Bebandem District, Karangasem Regency.

3. To analyze effective policy implementation models in poverty reduction in Bungaya Village at Bebandem District, Karangasem Regency.

\section{Theoretical Study}

The theoretical basis to build the conceptual framework of this research are third world development theory, community empowerment theory, and policy and public policy implementation theory.

\subsection{Types of Research}

This research uses a descriptive analytical qualitative research approach. Informants in this study are the Head of the Bali Provincial Village Community Empowerment and Government Agency (policy maker), the GSM Province Facilitator in Bali, the Head of the Bungaya Village, the Secretary and Chief of the Bungaya Village, the Management of the BUMdes (productive economy), Kelian Banjar in the Bungaya Village, and the program recipient group of Gerbang Sadu Mandara.

\subsection{Data Collection and Analysis Techniques}

Data collection techniques were carried out through observation, interviews, documentation and focus group discussions (FGD) with questionnaire instruments.

Data analysis was performed using simple mathematical and statistical methods, as follows:

The number of poor people who received the program of Mandara Integrated Village

Program Effectiveness $=$

Development Movement

X $100 \%$

the number of poor people in Bungaya illage

\section{Effectiveness of the Gerbang Sadu Mandara (GSM) Program in Poverty Alleviation in Bungaya Village at Bebandem District, Karangasem Regency}

\subsection{Effectiveness Based on Mathematical and Statistical Analysis}

1. The effectiveness of Gerbang Sadu Mandara.Program based on the number of poor residents in Bungaya Village from May 2012 to July 2014 was 34.15 percent. The level of effectiveness is categorized as low because it is still below 50 percent. This is because the number of poor people is greater than the number of program recipients, thus the level of effectiveness of the program is still low when measured through the documentation technique. 
2. Regarding the number of recipient groups, the effectiveness of Gerbang Sadu Mandara Program from May 2012 to July 2014 was 38.18 percent. Of the 165 groups / communities that utilize this program, only 63 groups have disregarded the installment process, the remaining 102 groups are still in the installment process. From these results it can be said that the of Gerbang Sadu Mandara in Bungaya Village has not been effective because of the low number of groups/ communities completing credit installment payments. Due to there are a lot of business capital given to various businesses that have not been healthy, especially in terms of financial management.

\subsection{Effectiveness Based on Secondary Data Analysis, Interviews and FGDs}

1. Based on the number of poor people, Bungaya Village is categorized entitled to get the Gerbang Sadu Mandara Program in the Province of Bali, where the poverty alleviation program targets rural areas that have a number of poor households of 35 percent.

2. Based on the ability to return installments, the Gerbang Sadu Mandara Program in Bungaya Village has not been effective because of the low number of groups/ communities completing credit installment payments, Due to there are a lot of business capital given to various businesses that have not been healthy, especially in terms of financial management.

3. The Effectiveness of the Gerbang Sadu Mandara Program Based on Interviews with Key Informants.

a. "The community is very enthusiastic about participating in this program under the auspices of the local village-owned enterprises, this can be reflected in the participation and input on managing communitybased socio-economic programs". (I Gede Partadana, SH, As a Guide and Advisor to the GSM Program in Bungaya Village).

b. At the beginning of the program the number of poor households was 1248 households, or 3,774 people. The realization of the GSM Program, especially in the productive economy sector is divided into community business groups that have various business fields continue to experience very rapid development, so that many groups or people are on the queue to receive this program in the form of venture capital. To overcome this problem the solution we have taken is to repay the installment money received from the previous revolving fund and give it to the group or community that has submitted a proposal, and has passed the verification stage. thus the funds in BUMdes do not settle and will continue to spin back to the RTM group in Bungaya Village. (I Nengah Cadra, SH Chairman of BUMdes Bungaya Village).

c. The existence of the village-owned enterprise (BUMdes) which is fully managed by BUMdes, is very effective in taking over the role and responsibility for managing poverty alleviation programs through low-interest venture capital loans. This is in line with the orientation and purpose of life of the Hindu community, namely mokshartam jagadhita ya caiti dharma (to realize the welfare of life in the world and the hereafter). With this philosophical basis, until now it is still relevant and widely adopted in Bali, the poverty alleviation program, through the Gerbang Sadu Mandara Program is more meaningful as a poverty alleviation program as one of the empowerment of the local resources of the village. (Dr. Drs A.A Oka Wisnumurti, M.Si, Province Facilitator on Management and Planning of the GSM Program).

4. The Effectiveness of the Gerbang Sadu Mandara Program based on FGD results, the recipient of the GSM program in the Focus Group Discussion said, the implementation of the GSM program involved program actors who were organized with one another in a hierarchy of interrelated tasks. BUMdes as the program implementation team (TPK) responsible for running the GSM program, is also transparent to the public about the management of funds and data of applicants for business capital loans and the verification stage of determining the amount of business capital to be provided.

The assistance is always through consultation with the village LPM, so we as one of the recipients of the GSM program feel comfortable, because of the social jealousy that usually arises between program recipients. Towards the size of the venture capital approved by the BUMdes through proposal requests. Asked about the effectiveness of the GSM program in Bungaya Village, the group said that this kind of transparency is what we hope to be in the management of program funds carried out by BUMdes to beneficiary communities, so that the expected effectiveness can be achieved (Chicken Livestock Business "Bhuana Mekar")

The above opinion was also approved by 2 groups of program recipients in Banjar Dukuh. They agreed to say that the Gerbang Sadu Mandara Program is the flagship program in poverty reduction, because in its implementation it really needs to be adjusted to the potential of the village, so that we can open our business without having to go elsewhere, even though we have to pay interest on loans, but we feel that the loan interest determined through the village meeting which is only 0.5 percent is very low, this has become one of the factors to spur us in opening a business through venture capital that is channeled through BUMdes. Asked about the effectiveness of the program, especially in Bungaya Village, both of them argued that community participation in providing assistance to this program, they were very 
enthusiastic about providing input to the Village and BUMdes as Program Implementers. Thus the harmonization of information that runs from the village or BUMdes with the recipient community of the program (Embroidery Business Group "Sari Nadi" and Ata Manufacturing Business Group" Jepun Putih").

Two recipient communities in Banjar Tihingseka said that in order to ensure the success of management tasks, both BUMdes, assistants and coaches in the implementation in the village, it was not enough with knowledge of the program, but attempted so that the GSM program successfully achieved the target well in accordance with the objectives that had been outlined. Therefore participation, active role and the importance of awareness of the position of the implementing task in this case BUMdes are expected to be able to realize communication, coordination and integration between the government and the needs of the community in the village. Asked about its effectiveness, we really felt the business capital assistance that we received so that we were able to develop a business making Pia and Dodol salak which would later be able to compete in a wider market, in this case BUMdes helped market our processed products and always innovated in developing our business . (Pia Salak and Dodol salak business group "PELITA HATI").

The opinion of the recipient of the program manners in Central Banjar said that the GSM program assistance to the community was not a permanent, constant aid but rather an incentive for the people's economy to advance. Government humanitarian assistance to residents who are still suffering (poor) like us is very useful. Business capital obtained from BUMdes is utilized as trading business capital. This trading business is one of the mainstay businesses in the village. Where the village has the 2 nd largest market in Karangasem Regency. Regarding the effectiveness of the GSM program in Bungaya Village, they said that the Gerbang Sadu Mandara program is implemented in the village in the hope of helping the poor, increasing their economic productivity and becoming independent and living well. At the same time giving meaning to the meeting of elements of government and society to work together in poverty reduction at the village level and it is hoped that there will be accountability in the form of a report from the village in this case BUMdes to evaluate the Gerbangsadu Mandara program. (Trade Group "Putri Mawar \& "Menuh" Group in Banjar Tengah).

5. The Effectiveness of the Gerbang Sadu Mandara Program Based on the Results of In-depth Interviews.

a. The success rate of the Gerbang Sadu Mandara Program in Bungaya Village is said to be of good quality. This is due to changes in the structure of community life that significantly underwent development with the existence of the program. The role of the community in innovating business is not limited so that the creativity of the program recipients can be best utilized by the recipient community groups in opening a business.

b. The success rate of the Gerbang Sadu Mandara Program is said to be quite successful. This is because the recipient community groups use the funds as venture capital. This triggers employment opportunities for the community and leads to an increase in people's daily income. The better program funds are used, the better the results obtained by these community groups. Lack of entrepreneurship training makes many people still doubt about what business can still be developed in their area. The community which consists of the majority of farmers must be keen to see business opportunities that might be developed in harmony with the potential that exists in the village.

c. Economically, the lives of the people, especially the recipient groups, experienced a significant increase. The more crowded village market activities indicate the better purchasing power of the people. This change in the economic life of the community depends on the efforts of the community in utilizing the funds provided.

d. The implementation of the Gerbang Sadu Mandara Program in the village of Bungaya runs on time. The intention of the community to have a business that continues to increase, this can be seen from the many requests for incoming financial assistance. This makes BUMdes as the program manager slightly defeated in determining program recipients. However, this problem can be resolved immediately. The solution provided is to roll back installments from residents who have received assistance to groups that have passed the verification stage and are on the queue list. This can be done considering the Bungaya Village has very good potential in business development, namely the existence of the 2 nd largest market in Karangasem Regency, with a fast turnover of money.

\subsection{Inhibiting Factors of Implementation of the Gerbang Sadu Mandara Program}

Based on data findings in the field there are a number of records that hamper the implementation of the Gerbang Sadu Mandara Program. including:

1. The Gerbang Sadu Mandara Program needs to increase its effectiveness in reaching out to marginalized groups. Evidence shows that they have not yet benefited from the program compared to other groups, including the poor in general. The participation of these groups in the decision making process is very limited because it is still dominated by elites and interest groups. 
2. The approach / procedure of the Gerbang Sadu Mandara Program has not yet had an impact on the planning and implementation of village development activities and other local governments.

3. Existing power structures (eg government, religious / traditional leaders) at the community / district level, who make decisions regarding more comprehensive development activities, remain unaffected by the program. Although these structures often assist and support the GerbangSadu Mandara Program system, they do not have the will or incentive to adjust the procedures of the Gerbang Sadu Mandara Program in other development projects or programs.

4. Timing of the Gerbang Sadu Mandara Program is close to the political agenda. One of them is the village head election.

5. The number of religious activities in the village coincided with the implementation of the Gerbang Sadu Mandara Program.

\subsection{Reconstruction of the Poverty Alleviation Policy Model}

The reconstruction of the poverty alleviation policy model needs to be pursued by encouraging the determination to reduce poverty so far, raising collective awareness to understand poverty as a common enemy, and increasing the participation of all parties in eradicating poverty. In general, the strategic programs that can be implemented to reduce poverty in villages are:

1). Opening up opportunities and business opportunities for the poor to participate in the economic development process. The government must create an atmosphere so that economic growth can be enjoyed by all levels of society, especially by the poor population. Therefore, policies and programs that favor the poor need to be focused on the real economic sector (for example, agriculture, marriages, manufacturing, small and medium businesses), especially in the informal sector which is the backbone of the poor. For economic growth to run and be sustainable, at the national level conditions are needed; (a) macroeconomic stability, especially low inflation rates and socio-political and economic environment that supports investment and innovation of economic agents. Broadly speaking, this is the responsibility of regional governments. b) a policy based on the partiality of the poor is needed so that they can fully utilize the opportunities that are open in the process of economic development; (c) give high priority to the policy and development of social facilities and physical facilities that are important for the poor, such as village roads, irrigation, schools, drinking water, clean water, sanitation, settlements, hospitals, and polyclinics in the regions.

2) Policies and programs to empower the poor. Poverty has a multidimensional in nature, so tackling it is not enough just to rely on an economic approach, but also rely on policies and programs in the social, political, legal and institutional fields. Policies in empowering the poor must be directed to give the poor access to the social, political and legal institutions that determine their lives. To expand access of the poor is needed; (a) good governance, especially government bureaucracy, legal institutions, and other public services; (b) Openness is required on the governmental order, public accountability, and law enforcement, as well as broad participation of the poor in the decision making process.

3) Policies and Programs that Protect the Poor. The poor community group is very vulnerable to internal shocks (for example the head of the family dies, illness, Termination of Employment) and external shocks (eg loss of work, natural disasters, social conflict), because they do not have the resilience or security in dealing with these shocks. Required policies and programs include efforts to; (a) reduce sources of risk of shocks; (b) increase the ability of the poor to cope with shocks and; (c) creating an effective social protection system.

4) Policies and Programs to break the inheritance of intergenerational poverty; children's rights and the role of women. Poverty is often passed on from one generation to the next. Therefore, the chain of inheritance of poverty must be broken. Improving the education and role of women in the family is one of the keys to breaking the poverty chain.

5) Policies and programs to strengthen village autonomy. Village autonomy can be a space that allows villagers to overcome poverty themselves. Sometimes the government considers that what the poor need is material resources for the survival of the poor. This assumption is not always true, because under certain conditions, poor rural people can get out of poverty without material assistance from the government. Initiatives and creativity can be valuable assets to escape poverty. . Village autonomy is a space that can be used by villagers to manage their initiatives and creativity well, becoming an abundant resource to escape poverty. An effective alternative policy implementation model for poverty reduction in Bungaya Village, Bungaya District, Karangasem Regency can be described as follows. 


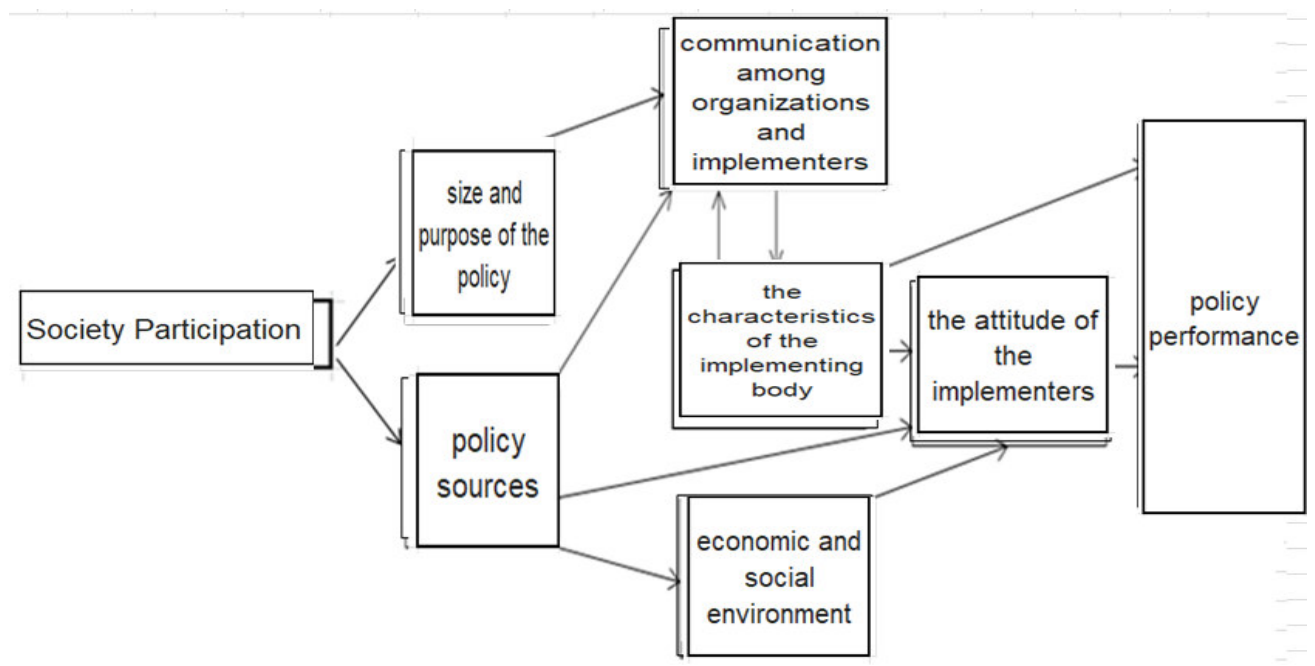

Figure: Alternative Model of the Process of Implementing Poverty Alleviation Policy with Participatory Approaches in Bungaya Village, Bebandem District, Karangasem Regency.

\section{Research Implications}

\subsection{Theoretical Implications}

Development always reminds us about idea of progress, prosperity, and wealth. Development endeavors are indeed for the sake of achieving those things. However, in practice, development often faces its own impasse. Current development practices and discourses, especially those related to poverty, are at a critical point due to various discrepancies and disparities.

So, if Robertson (Robertson: 1984) never considered development as the most ambitious collective effort of mankind, that would not be excessive. This is because development often fails to realize its ideals and instead plunges people to the brink of misery. The "modernization" approach as a development concept that has been applied by local governments has experienced moral uncertainty over development practices that often deviate from their original ideals and have eroded interpersonal concerns. He also made a lawsuit and sharp criticism of the foundations that underpin the development project that occurred in the Third World which often experiences paradoxes and impasse.

Various development projects in the name of poverty alleviation policies, which have been continuously encouraged and forced by developed countries against developing countries, including Indonesia, have turned out to be business-oriented by ignoring other dimensions. Or in Elizabeth Harrison's terms, the current development has become a monolithic development machine, which is only market-oriented, ready to roll and crush anyone who tries to block it. Development has lost the universal load which is oriented towards the benefits for the survival of humans and society.

In Indonesia, the indicator that can be seen from the failure according to Philip Quarles van Ufford Dik Roth is the occurrence of various very sharp inequalities. Starting from high unemployment and poverty rates, the problem of population equality, the discrimination in business opportunities, rural-urban and inter-regional disparities, to the income inequality among very disproportionate communities and so on.

Starting from this thought, theories about the empowerment of the poor still need to be criticized wisely so that an empowerment model can be found that can touch substantially and philosophically the root causes of poverty itself. And what is more important is how the empowerment has an impact on changes in the way of thinking and behavior of the poor to have an awareness independently of the problem of poverty.

\subsection{Practical Implications}

Poverty alleviation programs have not been maximized so far, alternative strategies and policies that favor the poor, options for the poor are an absolute necessity for poverty alleviation. To make an alternative strategy and policy, adequate knowledge is needed about the main causes of poverty in rural communities. From the series of causes of rural community poverty mentioned above, alternative strategies and policies to overcome village poverty can be done by:

1) Providing broad opportunities to the village community to obtain adequate and free education services. The government needs to develop a national education system which is oriented toward the poor (education for the poor). Education offered in Indonesia is currently very expensive and the costs are difficult to reach by poor people. Therefore, they choose not to send their children to school, because the burden of the existing education costs, is not proportional to their financial ability. Villagers often 
say that "not to send children to school, to eat every day is just hard to ask for forgiveness;

2) Opening broad opportunities for villagers to obtain easy business credit. The current credit system does not provide business facilities for rural communities and is often misplaced. Therefore, new policies are needed that provide adequate business credit guarantees for rural communities;

3) Meeting the needs of clothing, food, and village community boards. The need for clothing, shelter and food needs to be done through a village granary mechanism that provides equal opportunities to village communities, obtaining sources of needs that are provided in an organized manner;

4) Introducing modern agricultural systems with new technology that makes it easy for people to explore adequate sources of income. Agricultural technology is propagated and given free of charge to farmers to increase agricultural productivity and facilitate the fulfillment of their living needs;

5) Providing health insurance to the community with a free health service system, increasing community health centers (PUSKESMAS) and health service units to poor and underdeveloped villagers;

6) Providing insurance guarantees and social security to rural communities. Insurance and social security can improve the quality of life of the poor and provide a more meaningful life force. The current social insurance and insurance system, applied in a discriminatory manner, is only limited to those who have money. For this reason, the government is obliged to provide adequate insurance guarantees to the poor;

7) Strengthening executive and legislative commitments to improve government order. The current government structure provides flexibility for corrupt practices at all levels of government. Improving the governance structure is the key word for making poverty reduction programs truly intended for the poor; prioritize regions, development agenda. poverty eradication as the main priority scale, all parties to recognize failure.

\section{Research Proposition}

The successful implementation of poverty alleviation policies or programs is influenced by the ability of the bureaucratic apparatus to understand the reality of poverty and formulate it in a policy paradigm that is consistent with the dynamics of poverty alleviation.

The Process Model for Poverty Alleviation Policy Implementation Process with a Participatory Approach is very important to pay attention to community participation in addition to the basic capital owned by the poor, which includes social capital, human capital, financial capital, and physical capital. This basic capital is a factor that determines the implementation of poverty alleviation policies through a participatory approach, opening critical awareness of poor communities to be independent and to continuously empower themselves.

\section{Closing}

\subsection{Conclusion}

Based on the discussion above, the following conclusions are obtained:

1. The effectiveness of the Sadu Mandara Gate Program in the Province of Bali which is implemented in overcoming poverty in Bungaya Village is said to be less effective which only reaches 34.15 percent in terms of the number of program recipients. 38.18 percent when viewed from the perspective of the community who have completed the program, it is categorized as less effective because the level of effectiveness is below 50 percent. However, in terms of the implementation of the Gerbang Sadu Mandara program, it has been going well, this is proven by the increase in the amount of community income, making the community's standard of living better and opening up more jobs for the community so that the level of unemployment is less. This means, that the Gebang Sadu Mandara program in Bungaya Village is said to be going well, even though there are constraints such as the lack of socialization to the community in making proposals, the need for entrepreneurship training and training, and many people who have received programs have experienced delays in paying installments, thus this impedes the development of the Program and opportunities for other communities / groups who wish to obtain the Gebang Sadu Mandara Program.

2. The role of the Community Empowerment and Village Government Agency (BPMPD) in the Gerbang Sadu Mandara Program are as a leading sector in verifying proposals / completeness of administrative requirements for assistance requests. In this case the village concerned is given a good direction and oversight socialization. In monitoring the implementation of Gerbang Sadu Mandara, of course this task is not an easy task, it is expected to be transparent in all fields, and always establish good communication with the recipient of the program so that what is the target of the GSM program can be achieved according to mutual expectations.

3. The effectiveness of the Gerbang Sadu Mandara Program in Bungaya Village, although categorized as less effective, the implementation of this program has been going well, and has received a good response from the community. This can be seen from the overall results of the interviews of the quality indicators 
with measures of the quality of the implementation of programs that are categorized as good, the level of success of good programs, the existence of changes in the structure of life in the community significantly increased after receiving the program, as well as the time of the program implementation that runs on time as planned. Whereas if it is assessed from the quantity indicator, the amount of community income before receiving this program can be said to be still below the standard, but after receiving this program the number of people's income has experienced a significant change. The availability of wider employment opportunities for the poor to be able to be independent in developing their potential. Whereas if it is assessed from the quantity indicator, the amount of community income before receiving this program can be said to be still below the standard, but after receiving this program the amount of people's income has experienced a significant change. The availability of wider employment opportunities for the poor to be able to be independent in developing their potential. Judging from the relative poverty indicators, the influence of the Provincial Government's policy in poverty reduction efforts plays a big role. By using the concept of community empowerment based on the socio-economic community, community income has increased significantly, depending on the use of aid as capital in business. Based on structural poverty indicators, the direction of state policies that are based on the poor is urgently needed. With the hope that there will be a change in poverty rates in the direction of decline and the perceived importance of legal and government protection for the community. Judging from the indicators of cultural poverty, basically the character and culture of our nation has not been able to utilize the potential it has, as well as lifestyle and lack of creativity in innovating. Whereas judged by absolute poverty indicators, the level of income of the people categorized as poor are those who have below average income, as well as the level of family's ability to meet their daily needs that are lacking. However, these efforts can be overcome by the attention of the government to the community, one of which is by implementing various poverty reduction programs. This is seen from the change in economic productivity of the people receiving the program who feel an increase in income after receiving the Gerbang Sadu Mandara program. Likewise, policy indicators, in determining program recipients or targets, there is no element of political interest in them based on data from the Statistics Agency (BPS) on the Social Protection Program Approach (PPLS) in 2011 carried out by the National Team for the Acceleration of Poverty Reduction (TNP2K).

4. The inhibiting factors for the implementation of the GerbangSadu Mandara Program in the Province of Bali include:

a. Participation of poor groups in the decision-making process starting from program planning, implementation and evaluation is still very limited because it is still dominated by elites and interest groups

b. Policy makers, both formal and informal, have not contributed in a comprehensive manner, starting from program planning, implementation and evaluation because they do not have the will or incentive.

c. There are many other agendas (political and social religious) in the village which are carried out in conjunction with the Program Implementation

5. Reconstruction of poverty alleviation policy models needs to be pursued by encouraging poverty alleviation determination by raising collective awareness in order to understand poverty as a common enemy, and increasing the participation of all parties in eradicating poverty:

\subsection{Suggestions}

To overcome the existing problems, especially related to the participation of the parties, steps can be taken as follows:

a. Increasing efforts to disseminate information and training in making proposals for requests for assistance from the poor,

b. BUMdes, should be encouraged to play an active role in making direct approaches to the community, as well as fostering communities that have received programs.

c. In the implementation of programs related to channeling assistance to the poor in the form of credit that experiences obstacles in repayment, BUMDes needs to provide solutions to these problems through communication. This will form synergy between the government and the people who have the same goal in poverty alleviation efforts.

d. Local governments that issue poverty alleviation programs that are based on the socio-economic community, where the funds are managed by BUMdes, need to be established supervisory institutions that play an active role during the program, so that the above constraints can be overcome.

e. The Activity Implementation Team (TPK) in this case BUMdes needs to be more creative in managing business capital loan program, so that the poor can utilize this program appropriately, 
but always refer to the existing rules, such as the technical instructions for the activities and the rules that made and agreed by the community in local village deliberations.

f. In the provision of venture capital assistance, BUMdes are expected to pay attention to equity in each Banjar. This will reduce inequality in program development which in turn will also have an impact on reducing development disparities among Banjars in Bungaya Village.

g. Training on entrepreneurship must often be done to the community. This is very important for people who have a relatively low level of education, with the hope that through entrepreneurship training the community can think creatively and always innovate in business development in Bungaya Village.

h. The role of the local government through BPMPD Bali Province is very necessary to carry out monitoring activities, namely monitoring control, routine monitoring, and monitoring evaluation. BPMPD Bali Province with BUMdes need to communicate regularly in order to monitor the progress of the program, and evaluation that is intended as control and monitoring, both carried out routinely and at any time. Also required comprehensive coordination for all parties (stakeholders). With good communication it is expected that problems will arise when the implementation of the Gerbang Sadu Mandara program in the village will lead to a dialogue to find solutions to solve the existing problems.

\subsection{Policy Recommendations}

1) The success of poverty alleviation programs is influenced by the readiness of program recipients, therefore the recipients of the program must be prepared first.

2) The success of poverty alleviation programs is influenced by the level of discipline and responsibility of program recipients, therefore program recipients must first know the consequences of the programs to be implemented.

3) The success of the poverty alleviation program is influenced by the political agenda in the village, therefore the implementation of the poverty alleviation program is not implemented close to the political agenda in the village, such as the election of the village head

\section{REFERENCES}

Anonymous, 2013. Celebrating Inndonesia: Fifty Years with the Ford Foundation 1953-2003, Ford Foundation. Jakarta.

2014. Pembangunan yang Memihak Rakyat, Kupasan Teori dan Metode Pembangunan. Jakarta : Lembaga Studi Indonesia.

Adelma, Irma \& Robinson, Sherman, 1980. A Case Study of Korea. Cambridge: Oxford University Press.

Adelma, Irma. 2011. Cara Pendekatan Kepada Kebijakan Pembangunan Yang Terpusat Pada Kemiskinan, Pembangunan, Jakarta : UI Press. Dalam Mengkaji Ulang Strategi 1984. Beyond Export-Led Growth. Journal of World Development. Vol 12 (9).

Arsip Desa Bungaya dibidang Kepala Urusan Kesejahtraan Rakyat (2017)

Arsyad, Lincolin. 2011. Pertumbuhan dan Pemerataan, Dalam Teknik dan Manajemen Perencanaan Pembangunan. Yogyakarta : Kerja sama UGM, Depdagri, dan Bappenas.

Arsyad, Lincolin. 2011. Ekonomi Pembangunan. STIEYKPN, Yogyakarta.

Ary, D., Jacobs, \& L. C., Razavich, A. 2012. Introduction to Research In Education, Sixt Edition. United States: Wadsworth Group.

Badan Pusat Statistik (2011), Penduduk Miskin (Poor Population), Berita Resmi Statistik Penduduk Miskin, No. 04/Th.II/9, July, Jakarta: CBS

Badan Pusat Statistik (BPS), 2014, Analisis dan Tingkat Perhitungan Tingkat Kemiskinan 2007, Denpasar

Bogdan, R. C. \& Biklen, S. K. 2010. Qualitative Research for Education. an Introduction to Theory and Methods. Boston: Allyn and Bacon. Brox, O. 2006, The Political Economy of Rural Development: Modernization Without Centralization?, Eburon Publisher. Delfn.

BPMPD Provinsi Bali,2011, Program Gerbangsadu Mandara Membangun Penaggulangan Sistem, Plawasari, Denpasar.

Budiman, Arief. 2010. Teori Pembangunan Dunia Ketiga. Jakarta : PT Gramedia. Bungin, Burhan (Ed.), 2003, Metodologi Penelitian Kualltatif, Aktuallsasi

BUMdes Desa Bungaya, BUMdes Jagathita,2012,

Chamber, Robert (2010), Poverty and Livelihood: Whose Reality Counts, Discussion Paper 347, Brighton: Institute of Development Studies.

Chambers, Robert and Gordon Conway (2012), Sustainable Rural Livelihoods: Practical Concepts for the 21st Century, Discussion Paper 296, Brighton: Institute of Development Studies.

Comb, Philip H \& Manzoor Achmad, 2010 Memerangi Kemiskinan di Pedesaan Melalui Pendidikan Non-Formal 
(Diterjemahkan YIIS ), Jakarta.

Cox, David (2014), "Outline of Presentation on Poverty Alleviation Programs in the Asia-Pacific Region" makalah yang disampaikan pada International Seminar on Curriculum Development for Social Work Education in Indonesia", Bandung: Sekolah Tinggi Kesejahteraan Sosial, 2 Maret.

de Haan, L. J. 2010, "Globalization, Localization and Sustainable Livelihood", Soclologia Ruralls, Volume 40, Number 3, July 2010,

Dunham, Arthur, 2010 Community Welfare Organization, Princples and Praclice, New York : Thomas Y. Crowel Company,

Ellis, Frank (2012), "Household Strategies and Rural Livelihood Diversification", The Journal of Development Studies, Vol.35, No.1, pp.1-38.

Fear, F. A and Schwarzweller, H.K. 2012, "Introduction: Rural Sociology, Community and Community Development", in Fear, F. A

Galtung, J. 2010 On the Social Costs of Modemization: Social Disintegration, Atomie Anomie and Social Development.UNRISD. Geneva.

Hacker, H. 2011, Empowerment Projects for and by Woman: Summary of Pilot Study. DED Yaounde. (Unpublished).

Hargreaves, James R. (2017). "Hearing the Voices of the Poor : Assigning Poverty Lines on the Basis of Local Perception of Poverty. A Quantitative Analysis of Qualitative Data from Particitapory Wealth Ranking in Rural South Africa", Journal of WORLD DEVELOPMENT, Vol. 35, No. 2, pp.

Islamy, Irfan, 2017, Prinsip-Prinsip Perumusan Kebijakan Negara, Jakarta : Bumi Aksara.

Jakti, Dorodjatun Kuncoro,2010. Kemiskinam di Indonesia. Jakarta: Jayasan Obor Indonesia.

Jone, Charles, 0. 2910- Pengantar Kebijakan Publik. Jakarta : Citra Niaga Rajawali Press.

Kartasasmita, Ginanjar. 2010. Pembanguan untuk Rakyat, Memadukan Pertumbuhan dan Pemerataam. Jakarta : CIDES,

Korten, D.C. \& Sjahrir. 12011. Pembangunan Berdimensi Kerakyatan. Jakarta : Yayasan Obor Indonesia.

Korten, David C. 2011. Pembangunan yang Memihak Rakyat. Jakarta : Lembaga Studi Pembangunan.

Kuznets, Simon. 2010. Economics Growth and Income Inequality. Journal of American Economics Review. Vol. 45 (1).

Legawa Partha, I Nyoman Gede. 2012. Program CBD-Bali Sejahtera "Membangun Sistem Penanggulangan Kemiskinan yang Mandiri dan Berkelanjutan pada Desa Pakraman. Pelawa Sari. Denpasar

Lison, I Made. 2013. Efektivitas dan Pengaruh Program Penanggulangan Kemiskinan Terhadap Pemberdayaan Ekonomi Keluarga Prasejahtera di Kabupaten Badung. Tesis Program Pascasarjana Unud.Denpasar..

Mendola, Mariapia. 2017. Agricultural technology adoption and poverty eduction : A Propensity-score matching analysis for rural Bangladesh

Metodologis ke Arah Ragam Varlan Kontemporer, Jakarta: PT Raja Grafindo Persada.

Miles, M. B. \& Huberman, A. M. 2014. Qualiative Data Anaysis. Second Edition. USA : Sage Publications.

Moleong, L. J. 2015. Metodologi Penelltian Kualitatif. Bandung : PT Remaja Rosdakarya.

Mubyarto. 2010. Ekonomi Pancasila : lintasan Pemikiran Mubyarto. Yogyakarta : Aditya Media.

,2010 Kembali Ke Ekonomi Pancastla : Pemerataan, Pembangunan dan penanggulangan Kemiskinan. Yogynkarta : Aditya Media.

2011. Membangun Sistem Ekonomi, Yogyakarta : BPFE.

,2014 (b). Ilmu Ekonomi Baru Bagi Indonesia : Homo ekonomikus, Homo Sosios, dan Homo Etikus, Makalah disajikan dalam Seminar Nasional Pendidikan Koperasi Jurusan Ekonomi FIS-UNESA bekerja sama dengan Asosiasi Dosen dan Peneliti Koperasi (ADOPKOP) Indonesin, Surabaya, 22 Juli

Nasution, S.2010. Metode Penelitian Naturalistik-Kualitatif. Bandung : Rosdakarya.

Nugroho D., Riant 2010. Desentralisasi Tanpa Revolusi, Jakarta: Media Komputindo, Gramedia.

Osmani, S. R. 2010, "Participatory Governance, People's Empowerment and Poverty Reduction", SEPED Conference Paper Series No. 7. UNDP, Washington, D.C.

Ouibrida, M.G. \& Srinivasan, T.N. 2014. Introduction to Rural Poverty in Asia : Priority Issues and Policy Issues. Roxborough.

-------- 2014. Theories of Underdevelopment: Critical Social Studies, Macmillan, London.

Peet, R and Hartwick, E. 2010, Theories of Development, Guilford. New York and London.

Pranaka \& Tjokrowinoto, Moeljarto. 2011. Pemberdayaan (Empowerment) Dalam Pemberdayaan : Konsep Kebijakan dan Implementasi. Jakarta : CSIS.

Remi, Sutyastie Soemitro dan Tjiptoherijanto, Prijono, 2012, Kemiskinan dan Ketidakmerataan di Indonesia, Jakarta : PT Rineka Cipta Sajogio, 1987. Ekologi Pedesaan : Sebuah Bunga Rampal. Jakarta : Rajawali. 1993, Pemikiran Tentang Kemiskinan di Indonesia. Jakarta : MajalahPrisma No. 3 Tahun XII.

Schneider, H. 2010, Participatory Governance: The Missing Link for Poverty Reduction, OECD Development Center, Policy Brief No. 17. Paris 
Seligson, M. A and Passe-Smith, .1.2005, Development and Underdevelopment: The Political Economy of Global Inequality, Lynnc Rienner, Boulder.

Schwarzweller, H. K. (eds). 2012. Frank, A. G. 1978, "Dependent documulation and Underdevelopment", Macmillan. London.

Soemardjan et all, Selo, 2010. Kemiskinan Strukrural, Suatu Bunga Rampal.Jakarta: Sangkala Pulsar.

Solichin Abdul, 2012, Analisis Kebijakan dari Formulaxi Ke Implementasi Kebijaksanaan Negara Penerbit Bumi Aksara, Jakarta.

Spradley, J. P. 1997. Metode Etnografi Yogyakarta : PT Tiara Wacana

Sugiyono, 20015, Metode Penelitian Kuartitatif, Kualitatif, dan R\&D, Yogjakarta: Alfabeta

Supriatna, Tjahya, 2010. Strategi Pembangunan dan Kemiskinan. Jakarta: Rineka Cipta.

Surjono, Agus dan Nugroho, Trilaksono. Paradigma Model, Pendekatan Pembangunan, dan Pemberdayaan Masyarakat di Era Otonomi Daerah Malang : Lembaga Penerbitan \& Dokumentasi FIA UNIBRAW bekerja sama dengan Bayumedia Publishing.

Sutatwo, Hadiwigeno \& Agus Pakpahan. 2010 Identifikasi Wilayah Miskin di Indonesia. Majalah Prisma, No. 3 Tahun XII.

Syahdan, Gregorius, 2015, "Menanggulangi Kemiskinan Desa", Jurnal Ekonomi Rakyat, Edisi Tahun IV No. 2, Maret 2005, Yogjakarta.

Tjokrowinoto, Moeljarto. 2010. Konsep dan Isue Pembangunan Nasional, Yogyakarta : Program Studi MPA UGM.

2011 (a). Pembangunan, Dilema dan Tantangan. Yogyakarta : Prpgram Studi MPA UGM.

2012 (b). Konsep dan Isue Pembangunan Nasional. Yogyakarta : Prpgram Studi MPA UGM.

Usman, Sunyoto, 2016, Pembargunan dan Pemberdayaan Masyarakat, Yogjakarta : Pustaka Pelajar

Vyas, Vijas S. 2010 Struktur Agraria Masalah Lingkungan dan Kemiskinan Pedesaan, Jumal Agrockonomika, No. 2, Tahun XII.

Wahab, Solichin Abdul, 2010 Pengantar Analisis Kebijakan Negara Jakarta : Rineka Cipta.

Wallerstein, I. 2016, "A World-System Perspective on the Social Sciences, British Journal of Sociology, Vol. 27/3, pp. 343-352.

Warburton, D., 2012, Community and Sustainabe Development: Participation in the Future., Earthscan. London.

Widodo, Joko, 2014 Analisis Kebljakan Publik Konsep dan Aplikasi Analisis Proses Kebijakan Publik, Edisi 2, Malang : Bayu Media Publishing

Yin, Robert K., 2013. Studi Kasus : Desain dan Metode. (Diterjemahkan oleh Djauzi Mudzakir), Edisi 8, Jakarta : Raja Grafindo Persada 